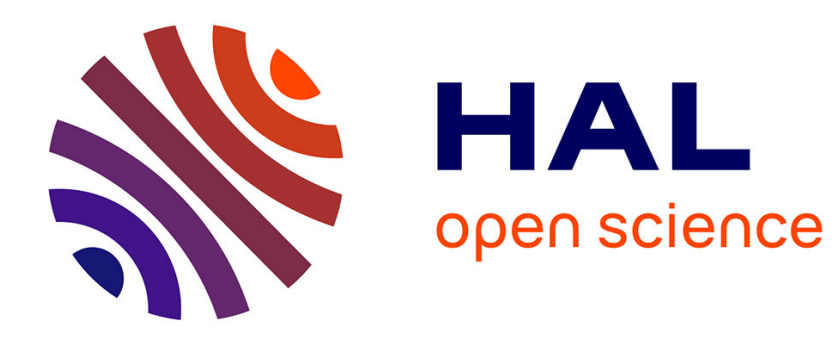

\title{
Profit Shifting and Equilibrium Principles of International Taxation
}

Manon François

\section{To cite this version:}

Manon François. Profit Shifting and Equilibrium Principles of International Taxation. 2021. halshs03265056v1

\section{HAL Id: halshs-03265056 \\ https://shs.hal.science/halshs-03265056v1}

Preprint submitted on 18 Jun 2021 (v1), last revised 23 Jul 2021 (v2)

HAL is a multi-disciplinary open access archive for the deposit and dissemination of scientific research documents, whether they are published or not. The documents may come from teaching and research institutions in France or abroad, or from public or private research centers.
L'archive ouverte pluridisciplinaire HAL, est destinée au dépôt et à la diffusion de documents scientifiques de niveau recherche, publiés ou non, émanant des établissements d'enseignement et de recherche français ou étrangers, des laboratoires publics ou privés. 


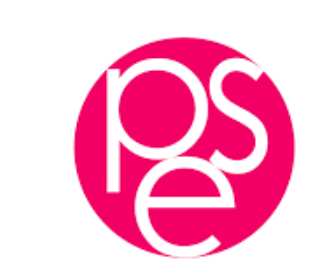

PARIS SCHOOL OFECONOMICS
ECOLE D'ECONOMIE DE PARIS

WORKING PAPER N ${ }^{\circ} 2021-43$

Profit Shifting and Equilibrium Principles of International Taxation

Manon François

JEL Codes: F23, H0, H25, H26, H71.

Keywords: tax competition, multinational firms, corporate taxes, transfer pricing.

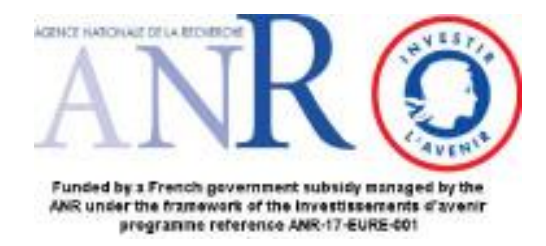




\title{
Profit Shifting and Equilibrium Principles of International Taxation
}

\author{
Manon Francois* \\ Paris School of Economics
}

June 2021

\begin{abstract}
We study the choice between source-based and destination-based corporate taxes in a twocountry model, allowing multinational firms to use transfer pricing to allocate profits across tax jurisdictions. We show that source-based taxation is a Nash equilibrium for tax revenue maximizing jurisdictions if domestic and/or foreign firms generate large revenues. We also show that destination-based taxes are a Nash equilibrium when firms generate low revenues, which implies the presence of multiple equilibria. Both the source and the destination principle coexist in equilibrium when domestic and foreign corporate revenues are average. However, the source principle always Pareto-dominates the destination principle.

JEL classification: F23, H0, H25, H26, H71
\end{abstract}

Keywords: Tax competition, Multinational firms, Corporate taxes, Transfer pricing

*Email: manon.francois@psemail.eu. Paris School of Economics, 48 Bld Jourdan, 75014 Paris. This paper previously circulated under the title "Profit Shifting and Destination-Based Taxes". I thank Gregory Corcos, Dhammika Dharmapala, Stephane Gauthier, Matthias Krapf, Florian Neumeier, Mathieu Parenti, Thomas Piketty, Ariell Reshef, Baptiste Souillard, Farid Toubal and Vincent Vicard, seminar participants at the Paris School of Economics and Paris 1 university and participants to the 2020 EALE, CIE, NTA and 2021 WIPE, CESifo on Public Economics and ZEW Public economics conferences. All remaining errors are mine. 
Multinational Firms (MNF) locate their profits in the different tax jurisdictions in which they operate in order to reduce their tax liability. ${ }^{1}$ The choice of a tax policy in a country will therefore trigger a reaction from those firms. ${ }^{2}$ The tax policy, in our framework, is composed of a statutory tax rate, a tax base and a tax enforcement level. ${ }^{3}$ Zooming in on the tax base, countries can decide to implement either a source-based or a destination-based tax system. The source system allows a government to tax profits if production occurs on its territory while the destination system allows to tax profits if production is sold on the territory, irrespective of the location of the production.

In the main strand of the literature studying the choice between the source and the destination principle, the tax rate is often exogenous and the tax base is not necessarily determined in equilibrium. In both the tax competition literature and the recent literature on destination-based taxes, statutory tax rates are rarely tax instruments governments choose endogenously (Georgakopoulos and Hitiris [1992], Grossman [1980], Auberbach and Devereux [2018]). We also observe that, in the corporate tax competition literature, tax bases are also almost never chosen endogenously (Devereux et al. [2008]).

This paper endogenizes the tax rate, tax base and tax enforcement responses of governments to study the uncooperative equilibrium choice between the source and the destination principle. ${ }^{4}$ It aims to shed light on a puzzle in which all countries, in practice, currently use the source principle while this tax system is considered suboptimal (Keen and Wildasin [2004], Lockwood [2001]). This choice between source-based and destination-based taxes gained some strength in 2016 when the US Congress proposed to shift the US source-based corporate tax system to a Destination-Based Cash-Flow Tax (DBCFT), ${ }^{5}$ which is considered optimal.

\footnotetext{
${ }^{1}$ For example, "Apple Sales International (ASI), [is] an entity that has acquired certain economic rights to Apple's intellectual property. Apple Inc. has used those rights of ASI to shift billions in profits away from the United States to Ireland, where it pays a corporate tax rate of $2 \%$ or less." Memo of the Permanent Subcommittee on investigations, 2013 (https://www.hsgac.senate.gov/subcommittees/investigations/hearings/ offshore-profit-shifting-and-the-us-tax-code_-part-2).

${ }^{2}$ Apple has, for example, moved part of its paper profits from Ireland to Jersey, another tax haven, after the US Subcommittee on Investigations raised the alarm on Apple's profit shifting behavior in Ireland (https://www.hsgac.senate.gov/subcommittees/investigations/media/ subcommittee-to-examine-offshore-profit-shifting-and-tax-avoidance-by-apple-inc).

${ }^{3}$ We abstract here from the role of deductions for capital expenses.

${ }^{4}$ The focus of this paper is on the choice between source and destination bases. We let aside all considerations regarding the choice between income taxation and cash-flow taxation.

${ }^{5}$ Tax Reform Task Force, 2017, A Better Way: Our Vision for a Confident America. (Initial version 2016)
} 
To rationalize this puzzle, we build a tax competition model with the presence of multinational firms (MNF). We model two countries that maximize their tax revenue using three levels of decision: they choose the tax base, the tax rate and the tax enforcement level. Multinational firms can engage in profit shifting by manipulating the transfer price of their intra-firm trade. This is the first paper, to the best of our knowledge, that gathers all three tax instruments endogenously.

We find that the source principle is the best-response to source-based taxes when domestic and/or foreign corporate revenues are large. Large profits entail a high source-based tax rate, which allows a source-based country to generate higher tax revenues than if it unilaterally adopted destination-based taxes. This high tax rate is possible because under the source principle, countries introduce a strict enforcement, thereby increasing the cost for firms to shift profits and thus to react to a high tax rate. We also show that for small values of corporate revenues, the best-response to the source principle is the destination principle. When foreign corporate revenues are small, the Home country does not give up on too much tax revenues by moving to destination.

Considering the best-response to destination-based taxes, we find that the destination principle is the best-response to destination-based taxes if domestic corporate revenues are small. Otherwise, when domestic corporate revenues are large, the best-response is the use of the source principle. As the level of enforcement in the destination-based country decreases, the destination principle becomes more likely to be the best-response. Indeed, if a country unilaterally adopts destinationbased taxes, it attracts profits, irrespective of its tax rate. All firms have an incentive to shift profits out of the source-based country and into the destination-based country. Therefore, the destination principle is part of a subgame perfect Nash equilibrium for small values of corporate revenues.

This implies that when both domestic and foreign corporate revenues are large, source-based taxation is a Nash equilibrium. Destination-based taxation is a Nash equilibrium for small values of corporate revenues. We thus observe that there can be a multiplicity of equilibria. When domestic and foreign corporate revenues are average, both principles coexist in equilibrium. However, the source principle Pareto-dominates the destination principle. The advantage of using source-based https://www.novoco.com/sites/default/files/atoms/files/ryan_a_better_way_policy_paper_062416.pdf. 
taxes, namely the possibility to tax foreign firms, compensates the drawback, namely the exposition to profit shifting, because the source-based country strictly monitors profit shifting. And thus, the advantage outweighs the absence of profit shifting under destination-based taxation.

Finally, we show that there does not exist any equilibrium with a unilateral adoption of the destination principle. The gravitational power of a destination-based country vis-a-vis profits is too important for the source-based country to levy enough tax revenues. We also show that our results are robust to variations to the model's assumptions.

The results of this paper have strong implications for tax policy. We find that source-based taxation can be an equilibrium and the existence of this equilibrium relies on the strict enforcement implemented under the source principle. Currently, we observe in many countries very low levels of profit shifting monitoring, which implies that source-based taxation is more distortive, and hence not necessarily revenue-maximizing. The results of this paper also suggests that the current international tax system could be the outcome of a noncooperative game played by rich countries maximizing tax revenues. Finally, it suggests that if one country were to unilaterally move to destination-based taxes, it would incentivize other countries to also adopt destination-based taxes, resulting in a new equilibrium with the universal adoption of the destination principle.

This paper first contributes to the literature regarding the optimality of source-based taxes relative to destination-based taxes by showing that the source principle can dominate the destination principle. Destination-based taxes are often considered optimal (Keen and Wildasin [2004], Lockwood [2001], Georgakopoulos and Hitiris [1992], Grossman [1980]). One argument put forward regarding corporate taxation is that destination-based taxes eliminate profit shifting (Auerbach et al. [2017]). However, some works have also shown that source-based taxes can dominate when taxes are set non-cooperatively (Lockwood [1993] with commodity taxation), or in the presence of imperfect competition (Keen and Lahiri [1998]). Our results sharply contrast with most of the existing literature. We show here that source-based taxation can be an equilibrium, which can Pareto-dominates the destination principle in a tax competition framework, with trade within multinational firms. 
It then contributes to the literature formalizing the implementation of a destination-based corporate tax. We first depart by endogenizing the tax rate, ${ }^{6}$ the tax base and the tax enforcement level, which are assumed exogenous in the literature. We also depart by focusing on the impact of destination-based taxation on tax revenues. The debate about destination-based taxes started in the 1990s but gained interest recently. ${ }^{7}$ Auberbach and Devereux [2018] and Becker and Englisch [2019] offer a formal analysis of the unilateral adoption of destination-based taxes. Bond and Gresik [2021] use the Auberbach and Devereux [2018] framework to study whether countries have a unilateral incentive to deviate from a multilateral DBCFT system using three tax policy parameters: the corporate tax rate, the level of deduction for capital expenditures, and the degree of border adjustment. We extend the approach of the above papers by introducing endogenous transfer price manipulation and strategic tax competition. It is crucial to take profit shifting through the use of transfer prices into account to study the strategic choice of tax policy since it represents enormous losses of tax revenues for most developed countries. ${ }^{8}$ Finally, Bond and Gresik [2020] study the economic effects of unilateral adoption of corporate tax policies in a heterogeneous firm model with transfer pricing. A notable difference with the literature is that we do not have endogenous capital accumulation which would naturally imply endogenous profitability. In this paper, the profitability of the input is exogenous.

This paper is also related to the literature on tax competition and extend the standard models by letting countries choose between source-based and destination-based taxes. Moreover, we not only analyze the complementarity of statutory tax rates but also pin down the expression of the best-response and equilibrium tax rates with respect to different tax systems, as well as equilibrium tax enforcement behaviors. Standard models focus on source-based taxation (Bucovetsky [1991],

\footnotetext{
${ }^{6}$ Bond and Gresik [2021] also endogenize the statutory tax rate.

${ }^{7}$ It started with Avi-Yonah [1993] and Bond and Devereux [2002] that first provided insights on the location and investment decisions of an MNF under both a source-based and a destination-based tax system without profit shifting or heterogeneity.

${ }^{8}$ In a recent contribution, Clausing [2020] shows that profit shifting costs the United States about $\$ 100$ billion a year (at 2017 tax rates). We also have evidence that profit shifting was responsible for a $\$ 8$ billion reduction of the tax base in France in 2008 (Vicard [2015]).
} 
Klemm and Liu [2019], Krautheim and Schmidt-Eisenlohr [2011]). ${ }^{9}$ In tax competition models as Zodrow and Mieszkowski [1986], Wilson [1986], Devereux et al. [2008], governments use the tax rates (both statutory and effective) as the only tax instruments. Last, the literature does not necessarily account for the profit shifting behavior of firms (Davies and Eckel [2010]).

The rest of the paper is organized as follows. Section 1 sets out the model assumptions. Section 2 solves the tax competition model for the equilibrium tax rates and enforcement levels. Section 3 develops the uncooperative equilibrium choice of tax system. Section 4 offers two extensions to the model to test the robustness of our results. Section 5 concludes.

\section{The model}

\subsection{Multinational firms}

There are two countries, Home and Foreign and each one faces a multinational firm. Each MNF consists of a parent and an affiliate. The parent of the Home multinational is located in Home and has its affiliate in Foreign. This affiliate produces one unit of an intermediate good at cost $c$, which is normalized to 0 . The good is then sold to its parent at some internal price $q$. This price, which is endogenously chosen by the MNF, is referred to as a transfer price. The parent earns a revenue $\pi$, yielding a profit equal to $\pi-q$ in Home. The parent profit is taxed at rate $\tau \geq 0$ by the Home government. The net profit of the parent is therefore $(1-\tau)(\pi-q)$.

The tax applying to the affiliate profit $q$ depends on the principle of international taxation in use in Foreign. If Foreign uses the destination principle, the profit of the affiliate $q$ remains untaxed in this country. If, on the contrary, Foreign uses the source principle, it levies a $\operatorname{tax} \tau^{*} q$, which implies a net profit of the affiliate equal to $\left(1-\tau^{*}\right) q$.

Under the destination principle, imports are subject to a border adjustment tax. If Home uses this principle, it taxes the revenue $q$ earned by the Home MNF from intra-firm trade at rate $\tau$. As a result, the net profit of the parent $(1-\tau)(\pi-q)$ is still reduced by $\tau q$. Finally the Home MNF

\footnotetext{
${ }^{9}$ See Wilson [1999], Devereux and Loretz [2013] and Heimberger [2021] for a literature review.
} 
thus gets $(1-\tau)(\pi-q)-\tau q$.

If the source principle is instead applied in Home, there is no border adjustment tax applying on the revenue $q$ earned by the Home MNF from intra-firm trade, maintaining the Parent net profit at $(1-\tau)(\pi-q)$. The border adjustment tax thus implies a differentiated treatment of imports and exports: Home imports are taxed at rate $\tau$ while its exports are left out of its tax base.

International taxation refers to the arm's length principle to restrict the manipulation of the transfer price set by the MNF. Assuming that the marginal cost is publicly observed, it costs $\alpha q^{2}$ to set a transfer price $q$ that departs from $c=0$. One can interpret this amount as a fine $q^{2}$ paid with probability $\alpha$, with $\alpha \in[\underline{\alpha}, 1]$ and $0<\underline{\alpha}<1$. This probability $\alpha$ is the enforcement level of the arm's length principle. The amount $\alpha q^{2}$ is called a concealment cost. ${ }^{10}$

We are now in a position to write down the expression of the Home MNF consolidated profit, i.e., the sum of the profits of the Home parent, its foreign affiliate and the concealment cost. To this aim, it is convenient to introduce a dummy variable $D$ (resp., $D^{*}$ ) that takes value 1 if Home (resp., Foreign) applies the destination principle, and 0 otherwise. For simplicity, we denote $S=1-D$, and $S^{*}=1-D^{*}$ the dummies corresponding to the use of the source principle. The net profit of a MNF located in Home can then be written as follows:

$$
\Pi=(1-\tau)(\pi-q)-D \tau q+\left(1-S^{*} \tau^{*}\right) q-\alpha q^{2}
$$

The net profit of a MNF whose parent is located in Foreign obtains in a symmetric way,

$$
\Pi^{*}=\left(1-\tau^{*}\right)\left(\pi^{*}-q^{*}\right)-D^{*} \tau^{*} q^{*}+(1-S \tau) q^{*}-\alpha^{*} q^{* 2}
$$

with a star indicating a Foreign variable.

\footnotetext{
${ }^{10}$ We focus on inbound profit shifting monitoring, which means that in this model, countries control the behavior of their domestic (importing) firms vis-a-vis transfer prices. We discuss the implications of outbound profit shifting monitoring (monitoring of exporting, and in this case foreign) firms in the conclusion.
} 
Let $\mathcal{P}=\{D, \alpha, \tau\}$ represent the policy chosen by Home, and $\mathcal{P}^{*}=\left\{D^{*}, \alpha^{*}, \tau^{*}\right\}$ the Foreign policy. Given $\mathcal{P}$ and $\mathcal{P}^{*}$, the transfer price $q\left(\mathcal{P}, \mathcal{P}^{*}\right)$ set by the Home MNF maximizes its profits $\Pi$ in (1). The profit is concave in $q$ and its global maximum obtains from the first-order condition,

$$
q\left(\mathcal{P}, \mathcal{P}^{*}\right)=\frac{(1-D) \tau-S^{*} \tau^{*}}{2 \alpha}
$$

Similarly, the transfer price of the Foreign MNF is $q^{*}\left(\mathcal{P}^{*}, \mathcal{P}\right)$.

$$
q^{*}\left(\mathcal{P}, \mathcal{P}^{*}\right)=\frac{\left(1-D^{*}\right) \tau^{*}-S \tau}{2 \alpha^{*}}
$$

The transfer price is negative if the MNF decides to set the transfer price below the marginal cost equal to 0 . The MNF then tries to shift profits out of the affiliate and toward the parent firm. Otherwise, the transfer price is positive.

\subsection{Governments}

Governments are assumed to maximize the total amount of collected taxes by choosing between the source and destination principles, the tax rates $\tau$ and $\tau^{*}$ as well as the levels of enforcement $\alpha$ and $\alpha^{*}{ }^{11}$ The tax collected by the Home government is

$$
T=\tau(\pi-q)+D \tau q+S \tau q^{*}
$$

In Foreign, it is

$$
T^{*}=\tau^{*}\left(\pi^{*}-q^{*}\right)+D^{*} \tau^{*} q^{*}+S^{*} \tau^{*} q
$$

Kawano and Slemrod [2016] show that the 37 OECD countries in their sample made 171 tax rate changes over the period 1980-2004. All countries in their sample have changed their top statutory tax rates. On the contrary, we observe that countries typically have stuck to the same tax enforcement policy over the past decades. This suggests to adopt the following timing: first governments choose in a non-cooperative way the tax principle, then their enforcement policies,

\footnotetext{
${ }^{11}$ We focus here on tax revenues. We consider that tax revenues are an important factor for policymakers when they choose their tax regime.
} 
and finally their statutory tax rates. The model is solved backwards.

\section{Equilibrium tax rates and enforcement policies}

In the last stage, we take as given the principles of international taxation and the enforcement policies $\alpha$ and $\alpha^{*}$, both between $\underline{\alpha}>0$ and 1. Assuming Nash behavior, the Home government takes the tax rate $\tau^{*} \geq 0$ chosen by Foreign as given and chooses $\tau \geq 0$ maximizing its tax revenue $T:$

$$
T=\tau\left(\pi-q\left(\mathcal{P}, \mathcal{P}^{*}\right)\right)+D \tau q\left(\mathcal{P}, \mathcal{P}^{*}\right)+S \tau q^{*}\left(\mathcal{P}^{*}, \mathcal{P}\right)
$$

under the constraint that the after-tax profit of the domestic MNF, net of all profit taxed abroad, is positive. ${ }^{12}$ This program makes it clear that the choice of the tax rates influences the allocation of profits across countries. In our model, tax competition will be induced by the MNF transfer pricing policy. Note that international mobility of profits does not transit through production location choices: the affiliate of the Home MNF always produces the input in Foreign. This may result from the existence of some location-specific intermediate good production in Foreign.

If the Home country uses source-based taxes, its best-response tax rate is: ${ }^{13}$

$$
\tau_{S}\left(\tau^{*} ; \alpha, \alpha^{*}\right)=\left[\frac{\alpha \alpha^{*}}{\alpha^{*}+\alpha}\right]\left[\pi+\frac{\tau^{*}}{2}\left(\frac{\left(1-D^{*}\right)}{\alpha^{*}}+\frac{S^{*}}{\alpha}\right)\right]
$$

This tax rate is positively related to the Foreign country tax rate if the Foreign country uses source-based taxation as well. This is the well-know pattern of tax competition arising with the source principle: countries compete over statutory tax rates, which can lead to a race to the bottom (Devereux et al. [2008]). If the Foreign country uses the destination principle, $\tau_{S}\left(\tau^{*} ; \alpha, \alpha^{*}\right)$ becomes independent of the tax rate of the Foreign country. Indeed, the input production of the Home affiliate is taxed in Home but not in Foreign, since it is not sold in Foreign (as can be checked in eq. (4)). In addition, the Foreign affiliate is taxed in Home but the border adjustment cancels out with the input cost deduction (see eq. (5)). The foreign input is therefore only taxed in Home. Firms from both countries will thus decide on their transfer price depending on the tax rate in

\footnotetext{
${ }^{12}$ We focus here on territorial taxation.

${ }^{13}$ The detailed computations are in appendix.
} 
Home, irrespective of the tax rate in Foreign.

If the Home country instead uses destination-based taxes, its best-response tax rate is:

$$
\tau_{D}\left(\tau^{*} ; \alpha, \alpha^{*}\right)=1+\frac{S^{*} \tau^{*}}{2 \alpha \pi}\left(1-\frac{S^{*} \tau^{*}}{2}\right)
$$

When both countries use destination-based taxes, the tax rates become independent of one another. There is no profit shifting and so no tax competition between countries. All MNF trade at arm's length. The universal use of the destination principle thus acts as a backstop to tax competition. However, when the Home country unilaterally uses the destination principle, its tax rate still depends on the source-based country tax rate. In this configuration, the transfer price enters the profit function of the Home MNF as a deduction, which provides the MNF with an incentive to lower the transfer price. This yields the positive relationship between both tax rates in (7b).

Symmetrically, Foreign takes the tax rate $\tau$ as given and maximizes

$$
T^{*}=\tau^{*}\left(\pi^{*}-q^{*}\left(\mathcal{P}^{*}, \mathcal{P}\right)\right)+D^{*} \tau^{*} q^{*}\left(\mathcal{P}^{*}, \mathcal{P}\right)+S^{*} \tau^{*} q\left(\mathcal{P}, \mathcal{P}^{*}\right)
$$

Its best-response tax rate writes as in (7a) and (7b), after permuting Home and Foreign indices.

Lemma 2.1. Consider a given principle of international taxation chosen by Home in $\{S, D\}$ and a given principle chose by Foreign in $\left\{S^{*}, D^{*}\right\}$. Given the enforcement policies $\alpha$ and $\alpha^{*}$, both in $[\underline{\alpha}, 1]$, there exists a unique pure strategy Nash equilibrium in the tax rate subgame,

$$
\tau=\left\{\begin{array}{lll}
\frac{4}{3} \frac{\alpha \alpha^{*}}{\alpha+\alpha^{*}} \frac{2 \pi+\pi^{*}}{2} & \text { if } & S=S^{*}=1 \\
1+\frac{\alpha^{*}}{\alpha+\alpha^{*}} \frac{\pi^{*}}{2 \pi}\left(1-\frac{\alpha \alpha^{*}}{\alpha+\alpha^{*}} \frac{\pi^{*}}{2}\right) & \text { if } & D=S^{*}=1 \\
\frac{\alpha \alpha^{*}}{\alpha+\alpha^{*}} \pi & \text { if } & S=D^{*}=1 \\
1 & \text { if } & D=D^{*}=1
\end{array}\right.
$$


The equilibrium tax rate $\tau^{*}$ set by the Foreign government obtains by symmetry, after permuting Home and Foreign indices in (9a) through (9d).

The equilibrium tax rate of a source-based country increases with the enforcement levels $\alpha$ and $\alpha^{*}$. When all countries use source-based taxation, profits are shifted to low-tax countries. If countries strictly monitor profit shifting, firms have less room for setting transfer prices that deviate from the arm's length price, which allows governments to set higher tax rates without loosing a significant amount of tax revenues. A country unilaterally using the source principle suffers from profit shifting towards the destination-based country, irrespective of its tax rate, and therefore prefers to monitor profit shifting. Indeed, a destination-based country attracts profits, irrespective of its tax rate as can be seen in eq. (3). In our model, since the government bears no cost of rising the enforcement level to 1 , it chooses to set $\alpha=1$ in equilibrium.

When Home unilaterally adopts the destination principle, the Home MNF has an incentive to declare low profits in its affiliate and to shift profits toward its parent firm in Home. The destination-based country thus has incentives to let firms shift profits and therefore $\alpha$ is low.

Finally, the equilibrium tax rates are both equal to 1 when both countries use the destination principle (eq. (9d)). Countries can choose such high tax rates without harming their potential tax revenues since MNF cannot shift profits across suitable choices of location of production activities.

We can now characterize the equilibrium enforcement policies. Given $\alpha^{*}$ and after reintroducing the expressions of the equilibrium tax rates $\tau$ and $\tau^{*}$ defined in Lemma 1 into (6) and (8), the bestresponse enforcement policy $\alpha$ of Home maximizes (6).

Lemma 2.2. Given the principles of international taxation in $\{S, D\}$ for Home and in $\left\{S^{*}, D^{*}\right\}$ for Foreign, if both countries apply the destination principle, then any $\alpha \in[\underline{\alpha}, 1]$ and $\alpha^{*} \in\left[\underline{\alpha^{*}}, 1\right]$ is a Nash equilibrium. Otherwise, the equilibrium enforcement policy of a country using sourcebased taxation involves a strict control of transfer pricing (it sets an audit probability of 1). The equilibrium enforcement policy of a country unilaterally using destination-based taxation involves a 
loose control of transfer pricing (it sets an audit probability of $\underline{\alpha}$ ).

Proof. See appendix.

When countries use the source principle, they strictly monitor profit shifting and incentivize MNF to trade at arm's length. Under a universal use of the source principle, countries compete on statutory tax rates and a high-tax country would loose taxable revenues as MNF shift profits to low-tax countries. Under a unilateral use of the source principle, since the destination-based country has the same gravitational power as a tax haven, the source-based country will suffer from profit shifting, irrespective of its tax rate. In both cases, the equilibrium solution is to prevent profit shifting by thoroughly controlling intra-firm trade.

The strict monitoring of transfer prices does not imply that there is no profit shifting by MNF headquartered in a source-based country. Since MNF differ in the revenue they make from selling the output, equilibrium tax rates are different. There thus exists an incentive for MNF to shift profits in equilibrium. Even though both source-based countries implement a strict monitoring of profit shifting, and hence firms will necessarily have to pay a fine, the tax saving is larger than the concealment cost. When one country unilaterally uses the destination principle, there is however no profit shifting in equilibrium because the source-based country decides to set its tax rate close to 0 to avoid facing a negative tax base.

When a country unilaterally uses the destination principle, it attracts profits no matter its tax rate. The destination-based country therefore has no incentives of monitoring profit shifting but should instead encourage it. The equilibrium is thus to enforce a loose control policy and $\alpha=\underline{\alpha}$.

Finally, under a universal use of the destination principle, since there is no profit shifting, the tax rates are independent of the tax enforcement levels and so $\alpha, \alpha^{*}$ can be set at any level. 


\section{Equilibrium principles of international taxation with symmetric countries}

All countries currently use source-based taxation and so decide to expose to fierce tax competition. In our setup, the race to the bottom of tax rates does not apply to the physical location of production activities, which is assumed to be given, but to the allocation of profits across tax jurisdictions that MNFs partially control through their transfer price policies. Instead, destination-based taxes, if used by all, would make countries immune to tax competition issues by rendering transfer prices a useless tool to reduce MNF tax liability. The main innovation of our paper is to discuss the outcome of a non cooperative choice of destination versus source-based taxation.

\subsection{Best-response to the source principle}

Suppose that Foreign uses source-based taxation $S^{*}$. Using the second and third stage equilibrium policy obtained in Lemma 1 and 2, one gets the taxes $T$ and $T^{*}$ defined in (6) and (8).

If Home uses the source principle, the collected tax revenue $T_{S S^{*}}$ writes as follows:

$$
T_{S S^{*}}=\left(\frac{2 \pi+\pi^{*}}{3}\right)^{2}
$$

Larger values of $\pi$ and/or $\pi^{*}$ favor the choice of source-based taxes in Home. If both countries use the source principle, they can both tax their domestic parent and the foreign affiliate. The collected tax $T_{S S^{*}}$ in (10) increases with $\pi$ and $\pi^{*}$ since both the tax rate $\tau_{S S^{*}}$ in $(9 \mathrm{a})$ and the tax base $\pi-q\left(\mathcal{P}, \mathcal{P}^{*}\right)+q^{*}\left(\mathcal{P}, \mathcal{P}^{*}\right)=\frac{2 \pi+\pi^{*}}{3}$ are increasing with $\pi$ and $\pi^{*}$.

When Home uses the destination principle, it is:

$$
T_{D S^{*}}=\pi+\frac{\pi^{*}}{2(1+\underline{\alpha})}-\frac{\pi^{* 2} \underline{\alpha}}{4(1+\underline{\alpha})^{2}}
$$

We observe that the collected tax $T_{D S^{*}}$ in (11) is also increasing in $\pi$ and $\pi^{*}$. Larger domestic corporate revenues $\pi$ imply a smaller equilibrium tax rate $\tau_{D S^{*}}$ but a larger tax base. Larger foreign corporate revenues do not impact the tax base and increase the equilibrium tax rate. Since the 
destination-based country attracts profits, a lower level of monitoring implies larger taxable profits and hence larger tax revenues. Under a unilateral adoption of the destination principle, the Home country can only tax its domestic firms, and therefore faces a higher opportunity cost of not taxing the exporting foreign firm if the foreign MNF generates large revenues.

Therefore, the Home country is indifferent between source and destination-based taxation when Foreign uses the source principle if and only if:

$$
T_{S S^{*}}-T_{D S^{*}}=0
$$

Equation (12) defines an ellipse. The pairs $\left(\pi, \pi^{*}\right)$ such that Home prefers destination-based over source-based taxation satisfy $T_{S S^{*}}-T_{D S^{*}}<0$. This defines the blue area in figure (1a). For $\left(\pi, \pi^{*}\right)$ located outside this blue area, the tax revenue difference $T_{S S^{*}}-T_{D S^{*}}$ is positive, which implies that the source principle is the best-response of Home to the source principle in Foreign.

Figure 1: Best-response to source-based taxes with $\underline{\alpha_{D S^{*}}}=\underline{\alpha_{D S^{*}}^{*}}=0.1$

(a) Best-response of Home

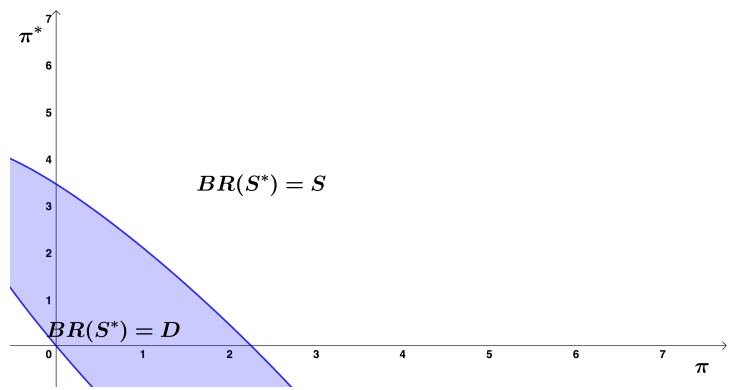

(b) Best-responses of Home and Foreign

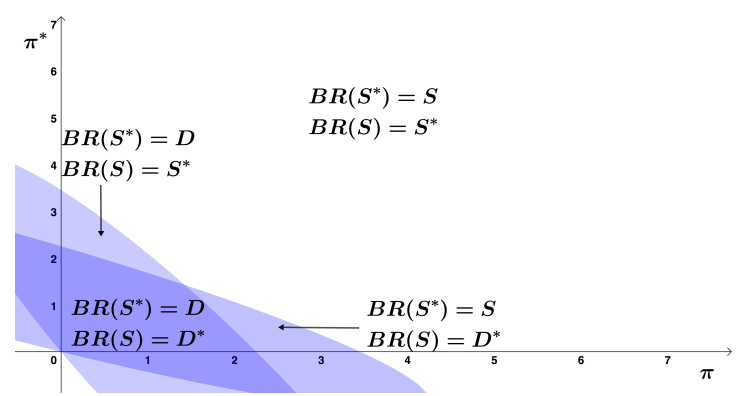

Note: Graphical representation of the tax revenue difference from equation (12) and the equivalent expression for the tax revenue difference for the Foreign country when $\alpha_{D S^{*}}=\alpha_{D S^{*}}^{*}=0.1 . \pi$ is represented on the horizontal axis and $\pi^{*}$ is on the vertical axis. Inside the blue area, the best-response to source-based taxes is destination-based taxes. Outside the blue area, the best-response is source-based taxes.

Proposition 3.1. The source principle is the best-response to source-based taxes when either or both foreign corporate revenues and domestic corporate revenues are large. Otherwise, the bestresponse to the foreign country using source-based taxes is the use of destination-based taxes.

As $\alpha_{D S^{*}}$ increases, the area where the destination principle is the best-response to the use of the 
source principle by Foreign decreases. More monitoring under a unilateral use of destination-based taxes favors the use of the source principle by Home, when Foreign uses the source principle. This comes from the fact that a country unilaterally using the destination principle attracts all the more profits if it sets a low level of enforcement.

Figure (1b) depicts the Foreign tax principle that is best-response to source-based taxes in Home. It shows that the universal use of the source principle will be part of a subgame perfect Nash equilibrium in pure strategies for $\left(\pi, \pi^{*}\right)$ large. This accords with the empirical observation that rich countries currently use source-based taxation.

\subsection{Best-response to the destination principle}

In the literature, the common wisdom is that "The unilateral adoption of a DBCFT would leave existing avoidance opportunities in place; however, they would operate to the detriment of the rest of the world, not that of the [destination-based tax] adopting country" ${ }^{14}$ This suggests that if, for some reason, one country decides to adopt the destination principle, the remaining (source-based) countries would be incentivized to move to destination-based taxes. That is, the destination principle would be a best-response of Home to the destination principle chosen in Foreign. We now assess this statement.

Suppose that the Foreign country uses the destination principle. The tax collected by Home when it uses the source principle writes is:

$$
T_{S D^{*}}=\frac{\pi^{2} \underline{\alpha}}{2(1+\underline{\alpha})}
$$

Instead, when both countries use the destination principle, the tax revenue collected by the Home country reduces to:

$$
T_{D D^{*}}=\pi
$$

\footnotetext{
${ }^{14}$ See Auerbach et al. [2017], p.40.
} 
Therefore, we find that Home is indifferent between source-based and destination-based taxes if:

$$
T_{S D^{*}}-T_{D D^{*}}=0 \Leftrightarrow \pi=\frac{2(1+\underline{\alpha})}{\underline{\alpha}}
$$

Figure 2: Best-response to the destination principle with $\underline{\alpha_{S D^{*}}}=\underline{\alpha_{S D^{*}}^{*}}=0.1$

(a) Best-response of Home

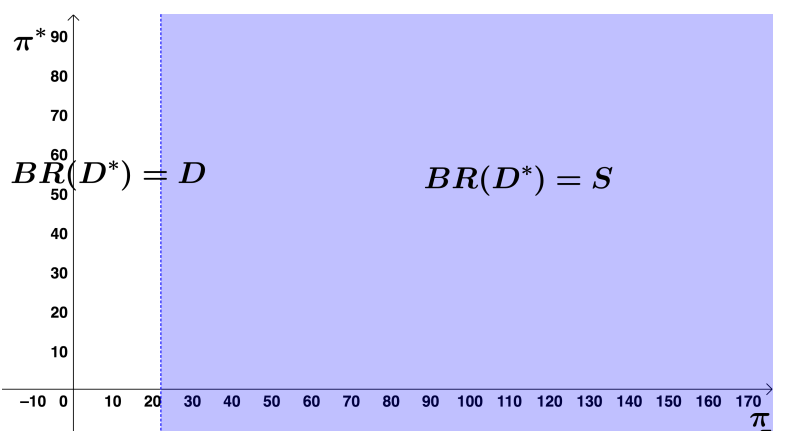

(b) Best-responses of Home and Foreign

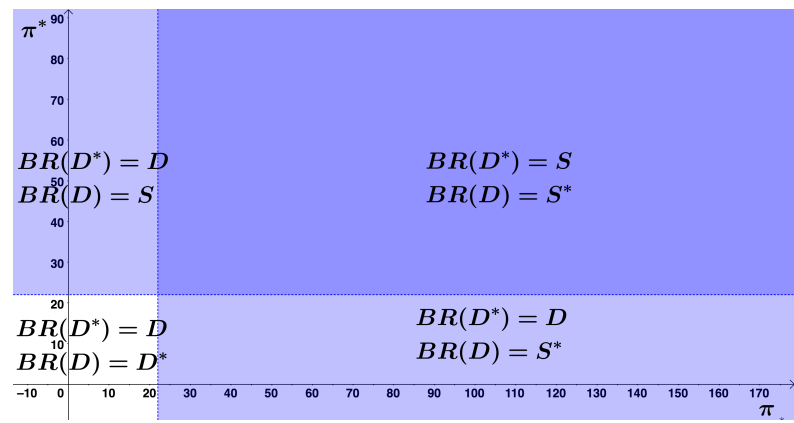

Note: Graphical representation of the tax revenue difference from equation (15) and the equivalent expression for the tax revenue difference for the Foreign country when $\alpha_{S D^{*}}=\alpha_{S D^{*}}^{*}=0.1 . \pi$ is represented on the horizontal axis and $\pi^{*}$ is on the vertical axis. Inside the blue area, the best-response to destination-based taxes is source-based taxes. Outside the blue area, the best-response is destination-based taxes.

Proposition 3.2. The destination principle is the best-response of Home to destination-based taxes when domestic corporate revenues are small. The source principle is the best-response of Home when domestic corporate revenues are large. As $\underline{\alpha_{S D^{*}}^{*}}$ tends to 0 , the area where destination-based taxes are the best-response increases.

The use of the destination principle entails larger tax revenues for the Home country than the use of the source principle when $\pi$ is small. The range of $\pi$ where the destination principle is the best-response to the destination principle increases as $\alpha_{S D^{*}}^{*}$ tends towards 0 . Less monitoring from the destination-based (Foreign) country implies a higher cost of profit shifting for the source-based (Home) country. Hence, if $\underline{\alpha_{S D^{*}}^{*}}$ is very low and close to zero, Foreign attracts most profits and Home is better off using destination-based taxes as well. As $\underline{\alpha_{S D^{*}}^{*}}$ gets larger, there is less profit shifting by the Foreign MNF and so, there exists a range of values for $\pi$ where Home is better off using source-based taxes. When its domestic firms generate large revenues, it chooses to tax them at a high tax rate, combined with a strict enforcement of the transfer pricing policy. 
Hence, as $\alpha_{S D^{*}}^{*}\left(\right.$ or $\underline{\alpha_{S D^{*}}}$ ) tends to 0 , there is no situation where one country decides to unilaterally use the source principle, once the other country has adopted the destination principle. The source-based country thus sets its tax rate close to 0 to avoid facing only negative taxable revenues. It therefore generates no tax revenues. This corroborates the intuition in Auerbach et al. [2017] that a universal adoption of the destination principle is possible.

\subsection{Equilibrium}

Propositions (3.1) and (3.2) provide us with preliminary characterizations of equilibrium tax principles: the source principle will be part of a subgame perfect Nash equilibrium in pure strategies when $\pi$ and/or $\pi^{*}$ is large, while the destination principle is always an equilibrium.

Proposition 3.3. The universal use of the source principle is part of a Nash equilibrium for large amounts of domestic and/or foreign corporate revenues. The universal use of the destination principle is part of a Nash equilibrium for small amounts of domestic and foreign corporate revenues.

Figure (3) illustrates three properties:

1. For any $\left(\pi, \pi^{*}\right)$, there exists an equilibrium.

2. For average values of $\pi$ and $\pi^{*}$, there exist multiple equilibria. Both the source principle and the destination principle are Nash equilibria.

3. We do not find any asymmetric equilibrium where one country uses the source principle and the other uses the destination principle.

When countries are symmetric, and strictly monitor profit shifting, they do not have an incentive to be the sole user of the source principle. On the one hand, strict monitoring limits the negative impact of tax competition. On the other hand, under a universal use of the destination principle, there is no profit shifting and hence no tax competition. The intermediate case with one country unilaterally adopting the destination principle creates a large imbalance between both countries. The destination-based country behaves as a tax haven by keeping exports out of its tax base and attracting profits, depending on its enforcement level. The source-based country looses 
tax revenue, no matter how low its tax rate is. As the enforcement level in the destination-based country decreases, Home has an increasing incentive to also adopt destination-based taxes. However, when the enforcement level in the destination-based country increases, Home has an incentive to use the source principle. Nonetheless, this is only the case for large values of domestic corporate revenues. And we know that, in this case, if Home uses the source principle, Foreign also chooses to use the source principle and therefore, there can be no unilateral equilibrium.

Figure 3: Equilibrium tax principle

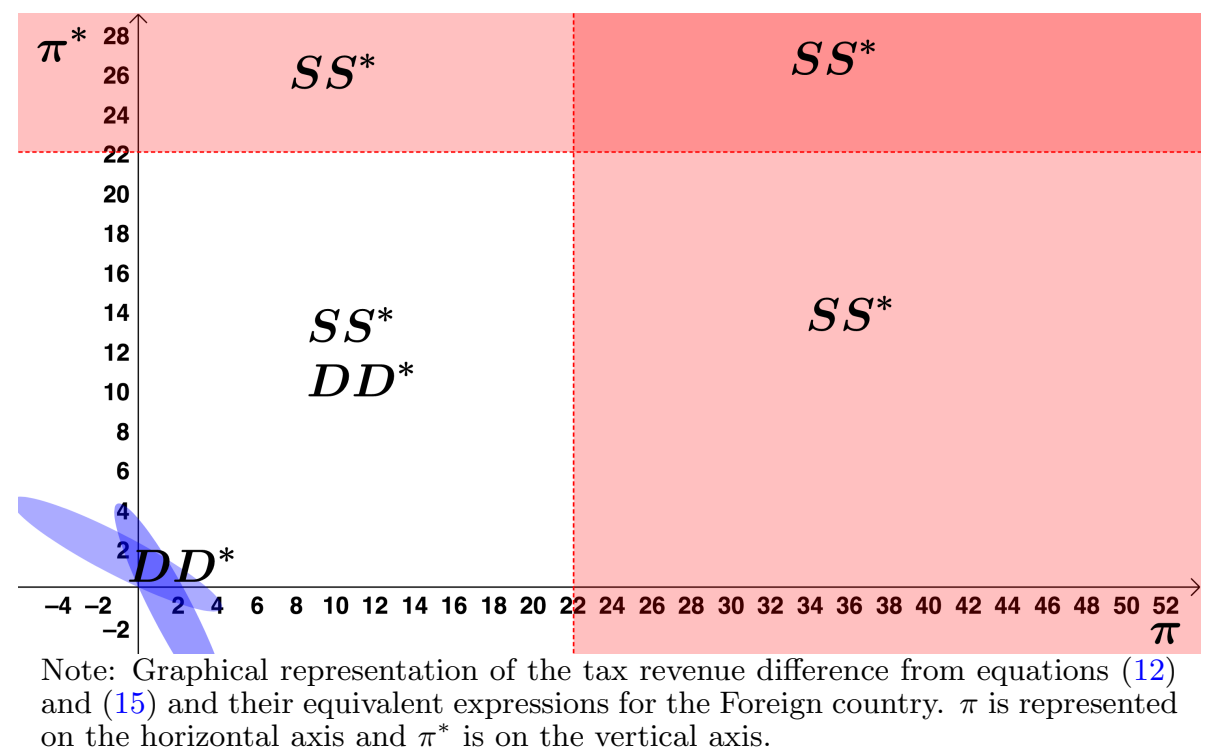

\subsection{Tax-Ranking of equilibria}

In the presence of multiple equilibria, we can rank the equilibria in terms of tax revenues for almost all $\left(\pi, \pi^{*}\right)$. The difference in the tax revenue collected in the two possible equilibria writes:

$$
T_{S S^{*}}-T_{D D^{*}}=\left(\frac{2 \pi+\pi^{*}}{3}\right)^{2}-\pi
$$

Figure (4) complements figure (3) by adding the black ellipse that represent the pairs $\left(\pi, \pi^{*}\right)$ such that the taxes $T_{S S^{*}}$ and $T_{D D^{*}}$ collected in equilibrium are equal (the difference given in (16) is zero). Below this line, the shaded region has $T_{D D^{*}}$ greater than $T_{S S^{*}}$; above this line, $T_{S S^{*}}$ is instead greater than $T_{D D^{*}}$. This again comes from the possibility of taxing foreign firms under the source principle. 
Figure 4: Pareto ranking of equilibria

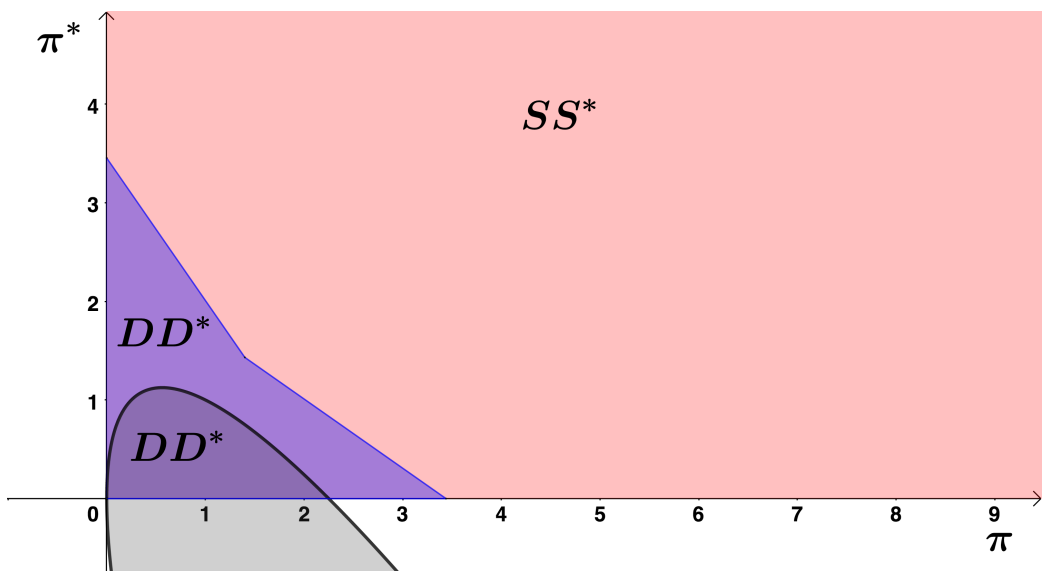

Note: Graphical representation of the tax revenue difference from equation (16). $\pi$ is represented on the horizontal axis and $\pi^{*}$ is on the vertical axis. The black ellipse represented is the solution to $T_{S S^{*}}-T_{D D^{*}}=0$. Below the ellipse, $T_{S S^{*}}<T_{D D^{*}}$ and above the ellipse, $T_{S S^{*}}>T_{D D^{*}}$. The red area above the blue lines represents the area where there are multiple equilibria as can be seen on figure (3).

Proposition 3.4. In equilibrium, the source principle always generates more tax revenues than the destination principle.

This result stands in sharp contrast with the well-known property establishing the superiority of the destination principle. This property is completely reversed in the presence of MNF that can use transfer pricing to allocate profits across countries. Here, governments are better off being exposed to tax competition while controlling MNF transfer pricing behavior. The reason is the following. The issue with the source principle is the tax competition countries are exposed to which lowers their tax rate and the profit shifting that harms their tax base. The advantage of the source principle is however that countries can tax both the domestic parent and the foreign affiliate, while with destination-based taxes, they can only tax the domestic firms. With an endogenous choice of enforcement level, tax competition due to profit shifting is reduced since countries strictly monitor profit shifting. Therefore, the source principle dominates in terms of collected taxes. 


\section{Robustness checks - variations to the model}

One limitation of this paper is that countries are identical and only hosts one multinational firm each. The results regarding the superiority of the source principle over the destination principle could come from this symmetry. A strict enforcement combined with the possibility of taxing both foreign and domestic MNF explains why the source principle yields more tax revenue in equilibrium than the destination principle. However, if countries were host to several MNF, without assuming that the number of firms is the same in both countries, the cost of giving up the right to tax the foreign affiliates with the destination principle would be reduced if there are only few affiliates. We consider this extension in the next section.

\subsection{Introducing asymmetry between countries}

We now assume that there are $N$ MNF headquartered in the Home country and $N^{*}$ MNF headquartered in the Foreign country.

The tax revenue difference replacing (12) when the Foreign country uses source-based taxation is:

$$
T_{S S^{*}}-T_{D S^{*}}=0 \Leftrightarrow \pi^{*}=\frac{9}{4}+\frac{9 N-8 N \pi}{4 N^{*}}
$$

This is represented by the green line on figure (5). The line rotates around point $A=(1.125$;

$2.25)$ as the ratio $\frac{N}{N^{*}}$ changes. At this point, the cost of profit shifting compensates the gain from taxing the foreign affiliate under the source principle.

When Home hosts a greater number of MNF parents than Foreign $\left(N>N^{*}\right)$, the smaller $\pi$ and the larger $\pi^{*}$ can be in order for the destination principle to be the Home best-response to the use of the source principle by the Foreign country. This means that Home chooses to use destination-based taxes if $\pi^{*}$ is moderately large relative to $\pi$ (up to a point) so that the large revenue generated by the Foreign firms can be compensated by the low revenue generated by the numerous domestic firms. Hence, Home decides to only tax its domestic firms. When the Foreign 
Figure 5: Best-response of the Home country to source-based taxes
(a) $\frac{N}{N^{*}}=1$
(b) $\frac{N}{N^{*}}>1$
(c) $\frac{N}{N^{*}}<1$
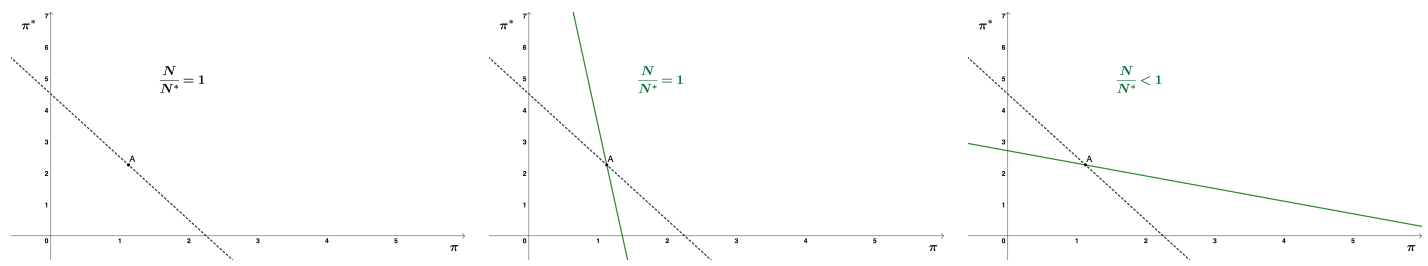

Note: Graphical representation of the tax revenue difference from equation (17). $\pi$ is represented on the horizontal axis and $\pi^{*}$ is on the vertical axis. Below the line, the best-response to source-based taxes is destination-based taxes. Above the line, the best-response is source-based taxes. The line itself represents the solutions to the equation $T_{S S^{*}}-T_{D S^{*}}=0$.

MNF generate larger revenues, it becomes too costly for the Home country not to tax the foreign firms and therefore, Home chooses the source principle.

Moreover, when the Home country becomes larger than the Foreign country, it risks becoming the high-tax country under source-based taxation. Indeed, when $N \pi>N^{*} \pi^{*} \Leftrightarrow \tau_{S S^{*}}>\tau_{S S^{*}}^{*}$. In that case, Home faces profit shifting. When its domestic firms generate low profits, Home cannot collect much revenue from its domestic parent firms and cannot fully tax foreign affiliates because they shift profits towards Foreign. Home therefore prefers to respond to source-based taxes by using destination-based taxes. However, when its domestic firms generate large revenues, Home can tax its numerous profitable firms at a high tax rate, which compensate the loss of tax revenue due to profit shifting. Finally, when $\tau_{S S^{*}}<\tau_{S S^{*}}^{*}$, Home chooses to use destination-based taxes because it can tax its domestic firms at a higher tax rate than under source-based taxation, which compensates for not taxing the foreign affiliates.

Conversely, when the Home country is smaller than the Foreign country, Home chooses to give up on taxing the numerous foreign affiliates only if its few domestic firms can generate enough revenue up to a point. When both the domestic and foreign firms generate large revenues, it prefers to use source-based taxes to benefit from taxing all firms.

Proposition 4.1. When considering countries asymmetric in terms of size, the larger the Home country gets, the bigger $\pi^{*}$ needs to be for the destination principle to be the best-response to the 
Foreign country using the source principle. Conversely, the larger the Home country gets, the bigger $\pi$ needs to be for the destination principle to be the best-response to the Foreign country using the source principle.

When the Foreign country uses destination-based taxation, the difference writes:

$$
T R_{S D^{*}}-T R_{D D^{*}}=0-N \pi<0
$$

The pattern is similar to the symmetric case. A source-based country prefers not to levy any tax revenues than to face negative taxable profits.

We show the equilibria and the Pareto-ranking of equilibria for $\frac{N}{N^{*}}=3$ in figure (6). The shape of the equilibrium is similar to that with symmetric countries. The larger the Home country compared to the Foreign country, the bigger the area where destination-based taxation is the only equilibrium. We still find multiple equilibria for an large values of both domestic and foreign corporate revenues.

We also find that the source principle always dominates the destination principle. Therefore, countries use destination-based taxation when corporate revenues are small and choose sourcebased taxation when corporate revenues are large.

We also find no possibility of existence of a unilateral equilibrium. Once a country moves to destination-based taxes, it will incentivize the other country to also adopt the destination principle by capturing all profits.

\subsection{If the enforcement level is exogenous}

Since there is no cost of profit shifting monitoring, the model implies that countries choose corner solutions in terms of tax enforcement: they strictly monitor profit shifting when they use sourcebased taxation and do not monitor at all when they use destination-based taxation. In practice,

enforcement levels are not that extreme. We aim here to test the stability of our results if the 
Figure 6: Equilibria and Pareto-ranking when $\frac{N}{N^{*}}=3$

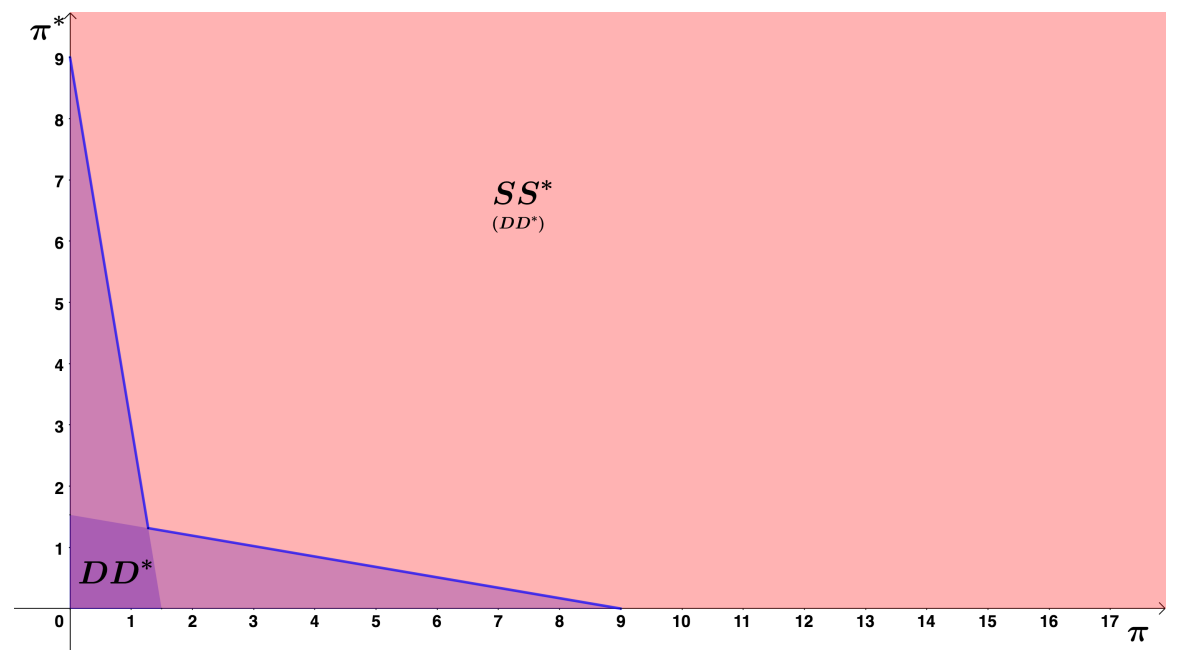

Note: Equilibria and Pareto-ranking of equilibria when $\frac{N}{N^{*}}=3 . \pi$ is on the horizontal axis and $\pi^{*}$ is on the vertical axis. The blue areas correspond to the values of $\pi, \pi^{*}$ where destination-based taxes are a best-response to the source principle. The red area represents the area where destination-based taxes are a best-response to the source principle for each country.

enforcement level is not either 0 or 1 . We consider in this section that the enforcement level is exogenous and study the impact of different values of enforcement levels on the equilibrium principle of taxation chosen by the Home country.

When the Foreign country uses source-based taxes, the collected tax of the Home country when it uses source-based taxes writes:

$$
T_{S S^{*}\left(\alpha, \alpha^{*}\right)}=\frac{\alpha \alpha^{*}\left(2 \pi+\pi^{*}\right)}{9\left(\alpha+\alpha^{*}\right)}
$$

When it uses destination-based taxes, it writes:

$$
T_{D S^{*}\left(\alpha, \alpha^{*}\right)}=\pi+\frac{\pi^{*} \alpha^{*}}{2\left(\alpha+\alpha^{*}\right)}-\frac{\alpha \alpha^{* 2} \pi^{* 2}}{4\left(\alpha+\alpha^{*}\right)^{2}}
$$

We observe that, if both countries decide to strictly monitor profit shifting, the area where destination-based taxes are a best-response to source-based taxes involves quite low values of $\pi^{*}$. This comes from the fact that strict monitoring under source-based taxes allows countries to face less profit shifting and set higher tax rates, which incentivizes countries to use source-based taxation. For the Home country, lowering $\alpha$ involves larger potential values of $\pi^{*}$ such that destination-based 
Figure 7: Best-response to source-based taxes

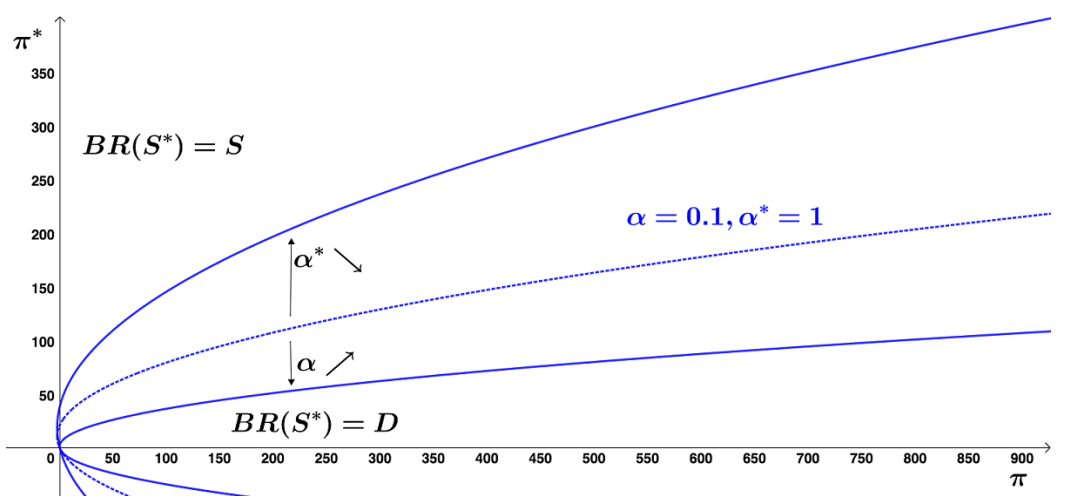

Note: Graphical representation of the tax revenue difference (19) - (20). $\pi$ is represented on the horizontal axis and $\pi^{*}$ is on the vertical axis. The blue ellipse represents the solutions to the equation $T_{S S^{*}}-T_{D S^{*}}=0$. Below the ellipse, destination-based taxes are the best-response to source-based taxes. Above the ellipse, source-based taxes are the best-response. The dotted line represents the case where $\alpha=0.1$ and $\alpha^{*}=1$.

taxes are a best-response. This is all the more the case if Home decides to strictly monitor profit shifting while Foreign chooses to set a low level of enforcement. If Foreign does not monitor profit shifting while using source-based taxes, it will choose a low tax rate, thereby attracting profits. Home is thus more likely to be better off with destination-based taxes, unless $\pi^{*}$ is really large. Finally, if both countries decide to set low levels of enforcement, Homes chooses the destination principle if $\pi^{*}$ is lower than $\pi$, which does not imply a large cost of not taxing the foreign affiliates and chooses the source principle for large values of both $\pi$ and $\pi^{*}$.

When the Foreign country uses the destination principle, the tax revenue difference writes:

$$
T_{S D^{*}}-T_{D D^{*}}=\frac{\pi^{2} \alpha \alpha^{*}}{2\left(\alpha+\alpha^{*}\right)}-\pi
$$

The tax revenue difference depends positively on both $\alpha$ and $\alpha^{*}$ and is independent of $\pi^{*}$. To the left of the lines, destination-based taxes are the best-response to destination-based taxes. To the right, source-based taxes are the best-response. For any $\pi^{*}$, the more monitoring from both countries, the bigger the area where source-based taxes are a best-response to destination-based taxes.

We study the equilibra with $\alpha=0.1$ and $\alpha^{*}=1$ in figure (9). The shape of the equilibria 
Figure 8: Best-response to destination-based taxes

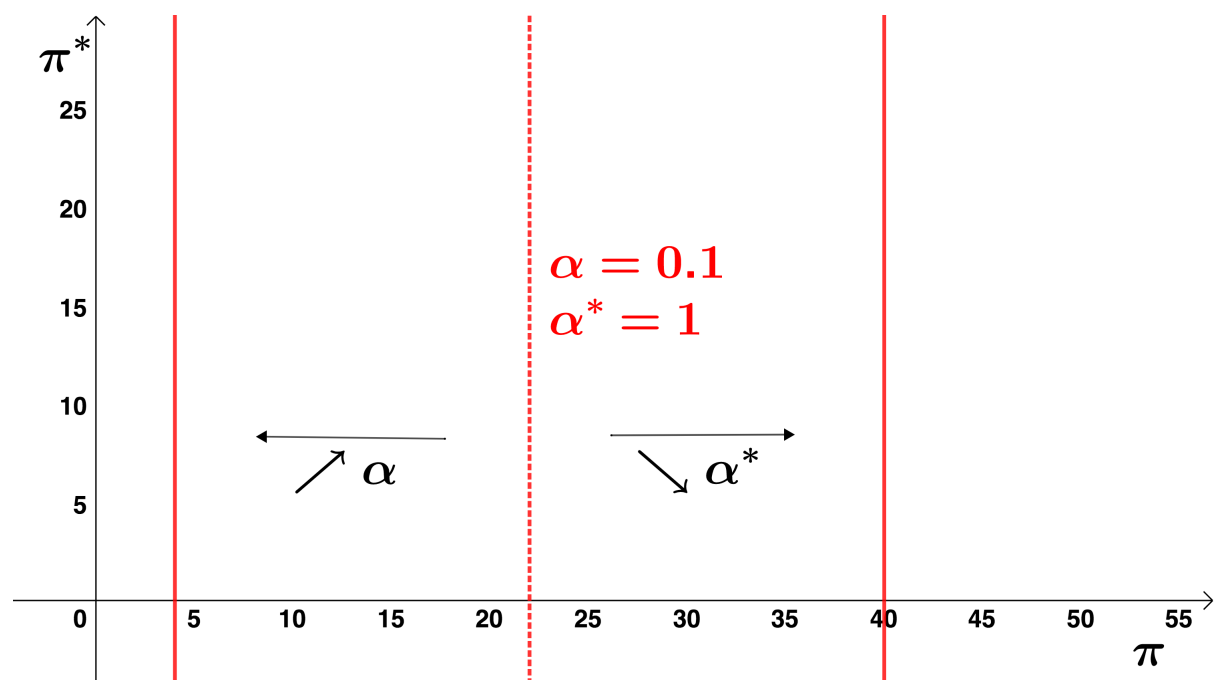

Note: Graphical representation of the tax revenue difference (21). $\pi$ is represented on the horizontal axis and $\pi^{*}$ is on the vertical axis. To the left of the lines, destination-based taxes are the best-response to destination-based taxes. To the right, source-based taxes are the best-response.

Figure 9: Equilibria and Pareto-ranking with $\alpha=0.1$ and $\alpha^{*}=1$

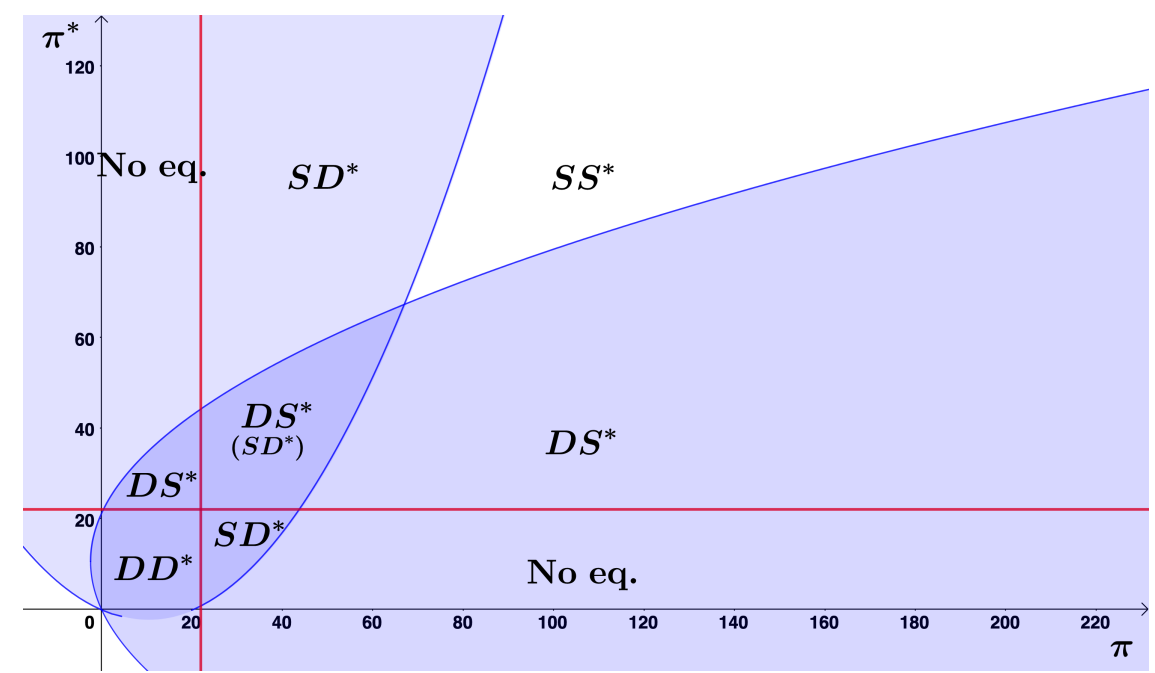

Note: Graphical representation of the tax revenue difference (21). $\pi$ is represented on the horizontal axis and $\pi^{*}$ is on the vertical axis. To the left of the lines, destination-based taxes are the best-response to destination-based taxes. To the right, source-based taxes are the best-response.

is similar for different values of $\alpha, \alpha^{*}$. We now observe the existence of unilateral equilibria with one country using the source principle and the other using the destination principle. The Home country decides to unilaterally use the destination principle for values of $\pi^{*}$ lower than $\pi$ or if $\pi^{*}$ is small, which means it uses destination-based taxes when the foreign MNF does not generate much revenues that Home cannot tax. Conversely, the Foreign country unilaterally uses the destination principle when the revenue generated by the Home MNF are not too large, relative to those of 
the foreign MNF. We also observe multiple equilibria for an intermediate range of values of $\pi$ and $\pi^{*}$ : both unilateral equilibria arise but we show that the unilateral use of the destination principle by the Home country Pareto-dominates the unilateral adoption of the destination principle by the Foreign country. This comes from the fact that we consider here that the Home country does not strictly enforce profit shifting monitoring which implies that it is therefore costly for Home to use the source principle.

The universal use of the destination principle is a Nash equilibrium for small values of both $\pi$ and $\pi^{*}$, while the universal use of the source principle is a Nash Equilibrium for large values of both $\pi$ and $\pi^{*}$. Finally, we observe that there is no equilibrium for either low $\pi$ or low $\pi^{*}$, outside of the square where the destination principle is an equilibrium. Consider the area where there exists no equilibrium and $\pi^{*}$ is small. In that area, Home has an incentive to adopt the destination principle when Foreign uses the source principle because its domestic MNF generate much more revenue than the foreign MNF. But the Foreign country also has incentives to adopt the destination principle if Home uses the destination principle. Since Home does not monitor profit shifting, Foreign will face profit shifted towards Home and will loose tax revenues. In that case, Home has incentives to unilaterally use the source principle because of its strict monitoring of its domestic firms.

Proposition 4.2. When the enforcement level is exogenous, the destination principle is a Nash equilibrium if MNF generate low revenues. If both MNF generate large revenue, the source principle is a Nash equilibrium. For either intermediate values of corporate revenues, or a large asymmetry between the revenue of the Home MNF compared to the Foreign MNF, the unilateral adoption of the destination principle by the richer country is a Nash equilibrium.

This shows that the level of tax enforcement plays a major role in this model. A strict enforcement favors source-based taxation. With low tax enforcement, being a high-tax source-based country makes it hard to raise tax revenues from multinational firms that try to escape taxation. There is evidence that auditing of multinational firms has decreased in several major countries. For the fiscal year 2017, the Internal Revenue Service (IRS), the governmental auditing institution in the US, audited only 331 of 616 corporate giants down from 431 audits in 2010. The number of agents working for that agency has also been reduced by a third in the last decade. This extension 
helps provide further intuition regarding the choice between source-based and destination-based taxation.

\section{Conclusion}

This paper focuses on the equilibrium choice of tax policy in a context of tax competition with transfer price manipulation by multinational firms. This aims to shed light on the following puzzle: the source principle is considered suboptimal in the literature but all countries use source-based corporate taxes. To solve this puzzle, we develop a model of tax competition in which countries endogenously choose their tax policy.

Our findings show that the equilibrium response of countries that use the source principle is to implement a strict monitoring of profit shifting. This strict monitoring lowers the distortions that are well known under source-based taxation, and hence the race to the bottom.

We find that with endogenous levels of tax enforcement and endogenous tax rates, source-based taxation is the best-response to the source principle if domestic and/or foreign revenues are large, which entails a high source-based tax rate. We also find that source-based taxes are the bestresponse to the destination principle also if domestic revenues are large, because of a high tax rate under source-based taxes which compensates the fact that a source-based country is penalized by the profit shifting behavior of firms. Overall, the universal use of the source principle is a Nash equilibrium if both domestic and foreign corporate revenues are large. The universal adoption of the destination principle is a Nash equilibrium for small values of corporate revenues. We find that when both domestic and foreign corporate revenues are average, both source-based and destinationbased taxation arise as equilibrium. However, the source principle Pareto-dominates the destination principle for large values of corporate revenues. Finally, we show that there does not exist

any unilateral equilibrium where one country uses the destination principle and the other uses the source principle. We also show that our results are robust to variations to the model's assumptions. 
This has strong tax policy implications. Source-based taxation can be an equilibrium because of the strict tax enforcement. Currently, we observe a decreasing and now low level of tax enforcement in many developed countries. This paper shows that governments should increase the level of monitoring of profit shifting when using source-based taxes. It also suggests that the current international tax system could be the outcome of a noncooperative game played by rich countries maximizing tax revenues. Finally, it shows that a country deciding to move to destination-based taxation could incentivize other countries to implement such a reform, implying a new worldwide equilibrium tax system immune to profit optimization.

This paper only considers the monitoring of inbound profit shifting. Assuming that countries control the profit shifting behavior of the foreign MNF (as in Peralta et al. [2006]) instead of that of the domestic MNF would not really impact the results. Countries would still have incentives to monitor profit shifting under the source principle and not to monitor under the destination principle. In equilibrium, we can expect the destination principle to be the equilibrium for small values of corporate revenues while the source principle would be the equilibrium (and dominating the destination principle in the case of multiple equilibria) for large values of corporate revenues. 


\section{References}

Auerbach, A.J. \& Devereux, M.P. (2018). Cash Flow Taxes in an International Setting. American Economic Journal: Economic Policy, American Economic Association, vol. 10(3), 69-94, August.

Auerbach, A.J., Devereux, M.P., Keen, M. \& Vella, J. (2017). Destination-Based Cash Flow Taxation. Oxford Legal Studies Research Paper No. 14/2017, Saïd Business School WP 2017-09; Oxford University Centre for Business Taxation WP 17/01.

Avi-Yonah, R.S. (1993). Slicing the Shadow: A Proposal for Updating U.S. International Taxation. Tax Notes 135, no. 10 (2012): 1229-34. (Originally published under the same title in Tax Notes 58 (1993): 1511)

Becker, J. \& Englisch, J. (2019). Unilateral Introduction of Destination Based Cash Flow Taxation." International Tax and Public Finance, Issue 27, 495-513.

Bond, S.R. \& Devereux, M.P., (2002). Cash Flow Taxes in an Open Economy. Centre for Economic Policy Research (CEPR) Discussion Paper 3401.

Bond, E.W. \& Gresik, T.A., (2020). Unilateral tax reform: Border adjusted taxes, cash flow taxes, and transfer pricing. Journal of Public Economics, Volume 184, 104160, ISSN 0047-2727.

Bond, E.W. \& Gresik, T.A., (2021). Can Destination-Based Cash Flow Taxes Arise in Equilibrium? CESifo Working Paper Series 8836, CESifo.

Bucovetsky, S., (1991). Asymmetric tax competition. Journal of Urban Economics, Volume 30, Issue 2, Pages 167-181, ISSN 0094-1190.

Clausing, K.A. (January 2020). How Big is Profit Shifting? Mimeo

Davies, R.B. \& Eckel, C. (2010). Tax Competition for Heterogeneous Firms with Endogenous Entry. American Economic Journal: Economic Policy, American Economic Association, vol. 2(1), 77102, February.

Davies, R.B., Martin, J., Parenti, M. \& Toubal, F. (2018). "Knocking on Tax Haven's Door: Multinational Firms and Transfer Pricing." The Review of Economics and Statistics, 100:1, 120134. 
Devereux, M.P. and Lockwood, B. \& Redoano, M. (2008). Do countries compete over corporate tax rates? Journal of Public Economics, Elsevier, vol. 92(5-6), 1210-1235, June.

Devereux, M.P. \& Loretz, S. (2013). What do we know about corporate tax competition? National Tax Journal, 66 (3), 745-774.

Georgakopoulos, T., Hitiris, T. (1992). On the Superiority of the Destination Over the Origin Principle of Taxation for Intra-Union Trade. The Economic Journal, 102(410), 117-126.

Grossman, H. (1980). Border tax adjustments: do they distort trade. Journal of International Economics 10 .

Heimberger, P., (2021). Corporate tax competition: A meta-analysis. European Journal of Political Economy, 102002, ISSN 0176-2680.

Kawano, L. and Slemrod, J. (2016). How do corporate tax bases change when corporate tax rates change? With implications for the tax rate elasticity of corporate tax revenues. Int Tax Public Finance 23, 401â433.

Keen, M. J. and Lahiri, S. (1998). The Comparison between Destination and Origin systems under Imperfect Competition. Journal of International Economics, 45(2), 323-350.

Keen, M. and Wildasin, D. (2004). Pareto-Efficient International Taxation. American Economic Review, 94 (1): 259-275.

Klemm, A. \& Liu, L. (December 2019). The Impact of Profit Shifting on Economic Activity and Tax Competition. IMF Working Paper No. 19/287.

Krautheim, S. and Schmidt-Eisenlohr, T. (2011). Heterogeneous firms, 'profit shifting' FDI and international tax competition. Journal of Public Economics, vol. 95, issue 1, 122-133.

Lockwood, B. (1993). Commodity Tax Competition under Destination and Origin systems. Journal of Public Economics, 52(2), 141-162.

Lockwood, B. (2001). Tax Competition and Tax Co-Ordination Under Destination and Origin systems: A Synthesis Journal of Public Economics 81, 279-319. 
Peralta, S. and Wauthy, X. \& van Ypersele, T. (2006). Should countries control international profit shifting?, Journal of International Economics Volume 68, Issue 1, Pages 24-37, ISSN 0022-1996.

Shaviro, D. (2010). The David R. Tillinghast Lecture: The Rising Tax Electivity of U.S. Corporate Residence. NYU Law and Economics Research Paper No. 10-45; NYU School of Law, Public Law Research Paper No. 10-72.

Vicard, V. (2015). Profit Shifting Through Transfer Pricing: Evidence from French Firm Level Trade Data. Banque de France Working Paper No. 555.

Wilson, J.D. (1986). A theory of interregional tax competition. Journal of Urban Economics, Elsevier, vol. 19(3), 296-315, May.

Wilson, J., (1999). Theories of Tax Competition. National Tax Journal, 52(2), 269-304.

Zodrow, G.R. \& Mieszkowski, P. (1986). "Pigou, Tiebout, property taxation, and the underprovision of local public goods." Journal of Urban Economics, Elsevier, vol. 19(3), 356-370, May. 


\section{Appendices}

\section{A Derivation of equations (7a) and (7b)}

We maximize (6) under the constraint that $\tau \geq 0$ and that the after tax profit of the domestic MNF, net of all profit taxed abroad is positive, i.e.:

$$
(1-\tau)(\pi-q)-D \tau q-\alpha q^{2} \geq 0
$$

To derive eq. (7a), we set $S=1$.

$$
\frac{\partial T}{\partial \tau}=0 \Leftrightarrow \tau_{S}\left(\tau^{*} ; \alpha, \alpha^{*}\right)=\left[\frac{\alpha \alpha^{*}}{\alpha^{*}+\alpha}\right]\left[\pi+\frac{\tau^{*}}{2}\left(\frac{\left(1-D^{*}\right)}{\alpha^{*}}+\frac{S^{*}}{\alpha}\right)\right]
$$

Similarly, to derive eq. (7b), we set $D=1$.

$$
\frac{\partial T}{\partial \tau}=0 \quad \Leftrightarrow \quad \tau_{D}\left(\tau^{*} ; \alpha, \alpha^{*}\right)=1+\frac{S^{*} \tau^{*}}{2 \alpha \pi}\left(1-\frac{S^{*} \tau^{*}}{2}\right)
$$

\section{B Proof of lemma 2.2}

\section{B.1 When both countries use source-based taxation}

The tax revenues of the Home country when both countries use source-based taxation write:

$$
\begin{gathered}
T_{S S^{*}}=\frac{2}{9} \frac{\alpha^{*} \alpha}{\alpha+\alpha^{*}}\left(2 \pi+\pi^{*}\right)^{2} \\
\frac{\partial T_{S S^{*}}}{\partial \alpha}=\frac{2}{9}\left(2 \pi+\pi^{*}\right)^{2} \frac{\alpha^{* 2}}{\left(\alpha+\alpha^{*}\right)^{2}}>0
\end{gathered}
$$

This implies $\alpha_{S S^{*}}=1$. By symmetry, we find that $\alpha_{S S^{*}}^{*}=1$.

\section{B.2 When the Home country unilaterally uses the destination principle}

The tax revenues of the Home country when it unilaterally uses destination-based taxation write: 


$$
\begin{gathered}
T_{D S^{*}}=\pi+\frac{\pi^{*} \alpha^{*}}{2\left(\alpha+\alpha^{*}\right)}-\frac{\left(\pi^{*} \alpha^{*}\right)^{2} \alpha}{4\left(\alpha+\alpha^{*}\right)^{2}} \\
\frac{\partial T_{D S^{*}}}{\partial \alpha}=-\frac{\pi^{*} \alpha^{*}}{4\left(\alpha+\alpha^{*}\right)^{3}}\left[2 \alpha+2 \alpha^{*}-\alpha \pi^{*} \alpha^{*}+\pi^{*} \alpha^{* 2}\right] \\
\frac{\partial^{2} T_{D S^{*}}}{\partial \alpha^{2}}=\frac{\pi^{*} \alpha^{*}}{2\left(\alpha+\alpha^{*}\right)^{4}}\left[2 \alpha+2 \alpha^{*}-\alpha \pi^{*} \alpha^{*}+2 \pi^{*} \alpha^{* 2}\right]
\end{gathered}
$$

We look for local extrema:

$$
\frac{\partial T_{D S^{*}}}{\partial \alpha}=0 \Leftrightarrow-2 \alpha-2 \alpha^{*}+\alpha \pi^{*} \alpha^{*}-\pi^{*} \alpha^{*} \alpha^{*}=0 \Leftrightarrow \alpha=\alpha^{*} \frac{2+\pi^{*} \alpha^{*}}{\pi^{*} \alpha^{*}-2}
$$

This extremum is unique. We study whether it is a maximum or a minimum. We evaluate the second partial derivative $\frac{\partial^{2} \tau}{\partial \alpha^{2}}$ at $\alpha=\alpha^{*} \frac{2+\pi^{*} \alpha^{*}}{\pi^{*} \alpha^{*}-2}$.

$$
\frac{\partial^{2} T_{D S^{*}}}{\partial \alpha^{2}}>0 \Leftrightarrow \pi^{*} \alpha^{* 2}>0
$$

The objective is convex. This local extremum is thus a global minimum.

The destination-based country best-response is found by comparing $\left.T_{D S^{*}}\right|_{\alpha=\alpha}$ and $\left.T_{D S^{*}}\right|_{\alpha=1}$.

At $\alpha=\underline{\alpha}, T_{D S^{*}}=\pi+\frac{\pi^{*}}{2(1+\underline{\alpha})}-\frac{\pi^{* 2} \alpha}{4(1+\underline{\alpha})^{2}}$

At $\alpha=1, T_{D S^{*}}=\pi+\frac{\pi^{*} \alpha^{*}}{2\left(1+\alpha^{*}\right)}-\frac{\left(\pi^{*} \alpha^{*}\right)^{2}}{4\left(1+\alpha^{*}\right)^{2}}$

We find that $\left.T_{D S^{*}}\right|_{\alpha=\underline{\alpha}}$ is larger than $\left.T_{D S^{*}}\right|_{\alpha=1}$ if $\pi^{*}>\frac{2 \underline{\alpha}+\alpha^{*}\left(2 \underline{\alpha}+2+2\left(\alpha^{*}\right)\right.}{\alpha^{*}\left(\underline{\alpha}-\alpha^{*}\right)}$. We know that $\frac{2 \underline{\alpha}+\alpha^{*}\left(2 \underline{\alpha}+2+2 \alpha^{*}\right)}{\alpha^{*}\left(\underline{\alpha}-\alpha^{*}\right)}<0$ since in equilibrium, $\alpha^{*}=1$, therefore, if $\pi^{*}>0, \alpha_{D S^{*}}=\underline{\alpha}$.

The source-based country tax revenues write:

$$
T_{D S^{*}}^{*}=\frac{\pi^{* 2} \alpha \alpha^{*}}{2\left(\alpha+\alpha^{*}\right)}
$$




$$
\frac{\partial T_{D S^{*}}^{*}}{\partial \alpha^{*}}=\frac{\pi^{* 2} \alpha^{2}}{2\left(\alpha+\alpha^{*}\right)^{2}}>0
$$

Therefore $\alpha_{D S^{*}}^{*}=1$. The equilibrium is thus $\left(\alpha_{D S^{*}}, \alpha_{D S^{*}}^{*}\right)=(\underline{\alpha}, 1)$. 